\title{
PENGARUH KOMPETENSI PEDAGOGIK, KOMPETENSI PROFESIONAL DAN KEPUASAN KERJA TERHADAP KINERJA GURU DI SMK NEGERI 4 MAKASSAR
}

\author{
Andi Paida \\ Fakultas Keguruan dan Ilmu Pendidikan, Universitas Muhammadiyah Makassar \\ email : andipaidahadli@gmail.com
}

\begin{abstract}
Abstrak
Kinerja profesional seorang guru terpengaruh oleh beberapa faktor seperti kompetensi dan kepuasan kerja. Idealnya, kompetensi yang wajib dimiliki oleh seorang guru yaitu kompetensi pedagogik, profesional, sosial, dan kepribadian. Sedangkan kepuasan kerja terkait dengan standar atau ukuran terpenuhinya hak dan kewajiban kerja seorang guru. Faktor penentu keberhasilan kinerja guru tersebut hingga saat ini belum mendapatkan kejelasan terkait faktor mana yang memiliki pengaruh yang lebih kuat terhadap kinerja profesional guru. Melaui penelitian ini, akan ditemukan kejelasan dari permasalahan tersebut. Penelitian ini bertujuan mengetahui pengaruh kompetensi pedagogik, kompetensi profesional, dan kepuasan kerja terhadap kinerja guru. Penelitian ini merupakan penelitian korelasional karena akan menguji adanya pengaruh variabel bebas terhadap variabel terikat. Pendekatan yang digunakan ada dua yaitu pendekatan kualitatif dan pendekatan kuantitatif. Penelitian dilaksanakan di SMK Negeri 4 Makassar. Data dalam penelitian ini terbagi menjadi (1) data kompetensi profesional guru, (2) data kompetensi pedagogik guru, (3) data kepuasan kerja, dan (4) data kinerja guru. Teknik pengumpulan data meliputi teknik observasi, wawancara, angket, dan dokumentasi. Analisis data meliputi, (1) analisis uji validitas butir soal, (2) analisis uji realibilitas instrumen, (3) uji persyaratan data meliputi uji normalitas dan uji linearitas, (4) analisis deksriptif, (5) uji hipotesis dengan uji T Parsial dan uji F.
\end{abstract}

Kata Kunci: Kompetensi, Pedagogik, Profesional, dan Kinerja.

\begin{abstract}
Abstrak
Kinerja profesional seorang guru terpengaruh oleh beberapa faktor seperti kompetensi dan kepuasan kerja. Idealnya, kompetensi yang wajib dimiliki oleh seorang guru yaitu kompetensi pedagogik, profesional, sosial, dan kepribadian. Sedangkan kepuasan kerja terkait dengan standar atau ukuran terpenuhinya hak dan kewajiban kerja seorang guru. Faktor penentu keberhasilan kinerja guru tersebut hingga saat ini belum mendapatkan kejelasan terkait faktor mana yang memiliki pengaruh yang lebih kuat terhadap kinerja profesional guru. Melaui penelitian ini, akan ditemukan kejelasan dari permasalahan tersebut. Penelitian ini bertujuan mengetahui pengaruh kompetensi pedagogik, kompetensi profesional, dan kepuasan kerja terhadap kinerja guru. Penelitian ini merupakan penelitian korelasional karena akan menguji adanya pengaruh variabel bebas terhadap variabel terikat. Pendekatan yang digunakan ada dua yaitu pendekatan kualitatif dan pendekatan kuantitatif. Penelitian dilaksanakan di SMK Negeri 4 Makassar. Data dalam penelitian ini terbagi menjadi (1) data kompetensi profesional guru, (2) data kompetensi pedagogik guru, (3) data kepuasan kerja, dan (4) data kinerja guru. Teknik pengumpulan data meliputi teknik observasi, wawancara, angket, dan dokumentasi. Analisis data meliputi, (1) analisis uji validitas butir soal, (2) analisis uji realibilitas instrumen, (3) uji persyaratan data meliputi uji normalitas dan uji linearitas, (4) analisis deksriptif, (5) uji hipotesis dengan uji T Parsial dan uji F.
\end{abstract}

Kata Kunci: Kompetensi, Pedagogik, Profesional, dan Kinerja.

\section{PENDAHULUAN}

Dunia pendidikan dipandang memiliki peranan penting dalam upaya terwujudnya kualitas sumber daya manusia. Peningkatan kualitas sumber daya manusia merupakan suatu proses yang tidak bisa terpisahkan dengan proses peningkatan pelayanan pendidikan oleh guru. Pengertian pendidikan menurut Undang-Undang Nomor 20 Tahun 2003 adalah usaha sadar dan terencana untuk mewujudkan suasana belajar dan proses pembelajaran agar peserta didik secara aktif mengembangkan potensi dirinya untuk memiliki kekuatan spiritual keagamaan, pengendalian diri, kepribadian, kecerdasan, alkhak mulia, serta keterampilan yang diperlukan dirinya, masyarakat, bangsa dan Negara.

Salah satu komponen tersebut adalah guru , karena guru secara intensif lebih mengenal dan berinteraksi terhadap peserta didik untuk 
membimbing, mengajar, melatih dan memfasilitasi. Menurut Wina Sanjaya (2007:13) "komponen sangat penting dalam mempengaruhi proses pendidikan adalah komponen guru. Hal ini memang wajar, karena guru merupakan ujung tombakyang berhubungan langsung dengan peserta didik yang menjadi objek dan subjeksuatu pembelajaran. Bagaimanapun bagus dan idealnya kurikulum, lengkapnya sarana, dan prasarana pendidikan, jika tanpa diimbangi dengan kemampuan guru dalam mengimplementasikan kesemuanya, maka semuanya akan kurang dan tidak bermakna”.

Sekarang ini, pemerintah menjadikan gur u sebagai salah satu pekerjaan profesional yan $\mathrm{g}$ menuntutnya untuk menguasai dan memenu hi beberapa persyaratan yang tidak mudah ber upa standar kualifikasi akademik dan

kompetensi guru, ini dilakukan guna memperbaiki kualitas pendidikan yang ada di Indonesia. Berdasarkan Peraturan Menteri Pendidikan Nasional Republik Indonesia Nomor 16 Tahun 2007 tentang Standar Kualifikasi Akademik dan Kompetensi Guru, dijelaskan bahwa Standar Kompetensi Guru dikembangkan secara utuh dari 4 (empat) kompetensi utama, yaitu: (1) Kompetensi pedagogik,(2) keperibadian, (3) sosial, dan (4) profesional. Keempat kompetensi tersebut terintegrasi dalam kinerja guru.

Berdasarkan hasil temuan di lapangan bahwa fenomena kinerja guru secara keseluruhan belum optimal, guru masih memiliki kendala-kendala yang dilakukan pada proses pembelajaran. Salah satunya yaitu kompetensi pedagogik yang dimiliki oleh guru. Seorang guru profesional dalam melaksanakan tugas harus memiliki kompetensi pengelolaan pembelajaran, kompetensi penguasaan akademik, dan kompetensi pengembangan potensi. Oleh karena guru adalah jabatan profesional maka kompetensi profesional guru mutlak diperlukan untuk dapat menciptakan proses pembelajaran yang baik.

Kepuasan kerja berkenaan dengan kesesuaian antara harapan seseorang dengan imbalan yang disediakan. Kepuasan kerja guru berdampak pada prestasi kerja, disiplin, dan kualitas kerjanya. Pada guru yang puas terhadap pekerjaannya maka kinerjanya akan meningkat dan kemungkinan akan berdampak positif terhadap peningkatan mutu pendidikan. Handoko dalam Sutrisno (2009:79) mengemukakan kepuasan kerja adalah keadaan emosional yang menyenangkan atau tidak menyenangkan bagi para karyawan memandang pekerjaan mereka.

\section{LANDASAN TERORITIS}

\section{Karakteristik Kompetensi}

Darsono (2011:123) menjelaskan Kompetensi merupakan karakteristik seorang pekerja yang mampu menghasilkan kinerja terbaik dibanding orang lain. Sedangkan kinerja orang kompeten dapat dilihat dari sudut pandang:

1) Kesuksesan, yaitu orang yang selalu sukses dalam bidang pekerjaan tertentu.

2) Kreativitas, yaitu orang yang selalu berpikir alternatif dalam memecahkan masalah dan setiap masalah yang dihadapi dapat dipecahkan.

3) Inovatif, yaitu orang yang mampu menemukan sesuatu yang baru, misalnya alat kerja

David R. Stone (dalam Uno, 2011:79) mengkategorikan karakteristik kompetensi ke dalam dua bagian, yaitu threshold competences dan differentiating competence. Threshold competence adalah karakteristik esensial (biasanya pengetahuan atau keterampilan dasar, seperti kemampuan membaca) yang seseorang butuhkan untuk menjadi efektif dalam pekerjaan, tetapi bukan untuk membedakan pelaku superior dari yang rata-rata. Differentiating competence adalah karakteristik yangmembedakan pelaku yang superior dari yang biasanya dalam pekerjaan.

Menurut Undang-Undang Nomor 14 Tahun 2005 Tentang Guru Dan Dosen, "Kompetensi adalah seperangkat pengetahuan, keterampilan, dan perilaku yang harus dimiliki, dihayati, dan dikuasai oleh guru atau dosen dalam melaksanakan tugas keprofesionalan".

Menurut Arifin (2011:38), Guru yang dinilai kompeten, apabila:

1) Guru mampu mengembangkan tanggung jawab dengan sebaik-baiknya

2) Guru mampu melaksanakan perananperanannya secara berhasil

3) Guru mampu bekerja dalam usaha mencapai tujuan pendidikan sekolah

4) Guru mampu melaksanakan peranannya dalam proses belajar mengajar di sekolah.

Guru adalah pendidik dan pengajar pada pendidikan anak usia dini jalur sekolah atau 
pendidikan formal, pendidikan dasar, dan pendidikan menengah. Guru-guru seperti ini harus mempunyai semacam kualifikasi formal. Dalam definisi yang lebih luas, setiap orang yang mengajarkan suatu hal yang baru dapat juga dianggap seorang guru.

Guru adalah profesi yang mempersiapkan sumber daya manusia untuk menyongsong pembangunan bangsa dalam mengisi kemerdekaan. Guru dengan segala kemampuannya dan daya upayanya mempersiapkan pembelajaran bagi peserta didiknya. Sehingga tidak salah jika kita menempatkan guru sebagai salah satu kunci pembangunan bangsa menjadi bangsa yang maju dimasa yang akan datang. Dapat dibayangkan jika guru tidak menempatkan fungsi sebagaimana mestinya, bangsa dan negara ini akan tertinggal dalam kemajuan ilmu pengetahuan dan teknologi yang kian waktu tidak terbendung lagi perkembangannya. Seorang guru yang mendidik banyak siswa dan siswi di sekolah harus memiliki kompetensi.

Berdasarkan Peraturan Pemerintah No.19 Th 2005, kompetensi yang harus dimiliki pendidik adalah kompetensi sebagai agen pembelajaran, yakni kemampuan pendidik untuk berperan sebagai fasilitator, motivator, pemacu dan pemberi inspirasi belajar bagi peserta didik. Kompetensi ini terdiri atas (a) kompetensi pedagogik, (b) kompetensi kepribadian, (c) kompetensi professional dan (d) kompetensi sosial.

\section{Kompetensi Pedagogik. \\ B. Kompetensi Pedagogik Guru}

Kompetensi pedagogik menurut Menurut Depdiknas (2008:4) adalah "kemampuan yang harus dimiliki guru berkenaan dengan karakteristik siswa dilihat dari berbagai aspek seperti moral, emosional, dan intelektual". Kemudian Majmudin (2008) bahwa yang dimaksud dengan Kompetensi Pedagogik adalah "Kemampuan pemahaman tentang peserta didik secara mendalam dan penyelengaraan pembelajaran yang mendidik".

\section{Kompetensi Profesional}

Kompetensi profesional yaitu kemampuan yang harus dimiliki guru dalam perencanaan dan pelaksanaan proses pembelajaran. Guru mempunyai tugas untuk mengarahkan kegiatan belajar peserta didik untuk mencapai tujuan pembelajaran. Untuk itu guru dituntut mampu menyampaikan bahan pelajaran. Guru harus selalu meng-update, dan menguasai materi pelajaran yang disajikan. Persiapan diri tentang materi diusahakan dengan jalan mencari informasi melalui berbagai sumber seperti membaca buku-buku terbaru, mengakses dari internet, selalu mengikuti perkembangan dan kemajuan terakhir tentang materi yang disajikan.

\section{Kinerja Guru}

Anton Moelyono dalam (Sri Iriyani, 2007:10) menyatakan bahwa kinerja adalah suatu yang dicapai, prestasi yang diperlihatkan atau kemampuan kerja. Dengan kata lain kinerja sama dengan prestasi kerja, dengan demikian kinerja guru adalah prestasi kerja yang dicapai oleh seorang guru dalam melaksanakan tugas yang dibebankan kepadanya. Wirawan (2009:5), kinerja adalah keluaran yang dihasilkan oleh fungsi-fungsi atau indikator-indikator suatu pekerjaan atau suatu profesi dalam waktu tertentu.

Berdasarkan Peraturan Menteri Pendidikan Nasional Republik Indonesia Nomor 16 Tahun 2007 tentang Standar Kualifikasi Akademik dan Kompetensi Guru. Dijelaskan bahwa Standar Kompetensi Guru dikembangkan secara utuh dari 4 kompetensi utama. (1) Kompetensi Pedagogik

Kompetensi Kepribadian (3) Kompetensi Sosial (4) Kompetensi Profesional. Standar kinerja perlu dirumuskan untuk dijadikan acuan dalammengadakan penilaian, yaitu membandingkan apa yang dicapai dengan apa yang diharapkan. Standar kinerja dapat dijadikan patokan dalam mengadakan pertanggung jawaban terhadap apa yang telah dilaksanakan. Indikator penilaian terhadap kinerja guru dilakukan terhadap tiga kegiatan pembelajaran dikelas yaitu (1) perencanaan program kegiatan pmbelajaran, pelaksanaan kegiatan pembelajaran, evaluasi pembelajaran.

\section{METODE PENELITIAN}

Penelitian ini menggunakan dua pendekatan, yaitu pendekatan kualitatif dan pendekatan kuantitatif. Pendekatan kualitatif dirancang dalam bentuk penelitian deskriptif (descriptive research) sedangkan pendekatan kualitatif dirancang dalam bentuk penelitian korelasional. Rancangan deskriptif digunakan karena peneliti berusaha untuk menjelaskan hasil penelitian dengan menggunakan tabel, gambar dan grafik mengenai data yang telah 
diolah. Sedangkan rancangan korelasional digunakan karena peneliti berusaha untuk menjelaskan pengaruh variabel independen (independend variables) terhadap variabel dependen (dependend variables).

Penelitian ini dilakukan di SMK Negeri 4 Makassar. Waktu penelitian dilaksanakan selama lima bulan, yaitu dari bulan April 2017 sampai dengan Agustus 2017. Sedangkan teknik pengumpulan data yang digunakan dalam penelitian ini, yaitu: kuisioner dimaksudkan untuk menjaring data semua variabel dalam penelitian ini; Observasi, bertujuan untuk menjaring data yang tidak dapat dijaring oleh data koesioner; dan Wawancara memiliki fungsi yang sama dengan observasi. Instrumen ini bertujuan untuk menjaring data yang tidak terjaring oleh instrumen angket.

\section{HASIL DAN PEMBAHASAN}

\section{Hasil Uji Validitas dan Reliabilitas Instrumen}

Dalam melakukan penelitian ini penulis menggunakan instrumen berupa kuesioner yang terdiri dari variabel kompetensi pedagogik sebanyak 30 item, kompetensi profesional sebanyak 8 item, kepuasan kerja sebanyak 20 item dan kinerja guru sebanyak 12 item pernyataan. Untuk mengukur kevalidan dan reliabilitas instrumen, maka peneliti melakukan uji coba instrumen terhadap 10 orang guru di SMKN 4 Makassar. Uji validitas dan reliabilitas ini menggunakan program SPSS dengan menggunakan fungsi scale, reliability snalysis, statistic if item deleted, correlation, model alpha. Hasil pada kolom correlated item total correlation menununjukkan nilai validitas butir instrumen. Setiap butir dinyatakan valid jika nilai correlated item total correlation lebih besar dari nilai $\mathrm{r}_{\text {tabel }}$ dengan taraf signifikansi $5 \%$ atau 0,707 . Selanjutnya, instrumen dinyatakan reliabelatau terpercaya jika nilai pada kolom Cronbach's Alpha if Item Deleted lebih besar dari nilai $\mathrm{r}_{\text {tabel }}$ dengan taraf signifikansi $5 \%$ $(0,7)$ maka butir instrumen dinyatakan reliabel. Dengan demikian, setelah memenuhi syarat tersebut, instrumen dinyatakan layak untuk digunakan dilapangan dengan hasil data yang dikumpulkan pun terpercaya. Adapun hasil uji validitas dan reliabilitas instrumen penelitian ini sebagai berikut:

Tabel 4.1 Validitas Butir Instrumen

\begin{tabular}{cccccc}
\hline & $\begin{array}{c}\text { Scale Mean if Item } \\
\text { Deleted }\end{array}$ & $\begin{array}{c}\text { Scale Variance if } \\
\text { Item Deleted }\end{array}$ & $\begin{array}{c}\text { Corrected Item- } \\
\text { Total Correlation }\end{array}$ & $\begin{array}{c}\text { Squared } \\
\text { Multiple } \\
\text { Correlation }\end{array}$ & $\begin{array}{c}\text { Cronbach's Alpha if Item } \\
\text { Deleted }\end{array}$ \\
\hline item1 & 1291,0000 & 14232,222 &, 718 &. &, 927 \\
\hline item2 & 1292,0000 & 13551,111 &, 803 &. &, 921 \\
\hline item3 & 1288,0000 & 13884,444 &, 884 &. &, 922 \\
\hline item4 & 1288,0000 & 13884,444 &, 784 &. &, 922 \\
\hline item5 & 1288,0000 & 13884,444 &, 784 &. &, 920 \\
\hline item6 & 1290,0000 & 13644,444 &, 755 &. &, 921 \\
\hline item7 & 1290,0000 & 13511,111 &, 729 &. &, 921 \\
\hline item8 & 1291,0000 & 13698,889 &, 793 &. &, 922 \\
\hline item9 & 1292,0000 & 13284,444 &, 941 &. &, 931 \\
\hline item10 & 1297,0000 & 13312,222 &, 872 &. &, 923 \\
\hline item11 & 1301,0000 & 13921,111 &, 788 &. &, 922 \\
\hline item12 & 1290,0000 & 13733,333 &, 788 &. &, 924 \\
\hline item13 & 1293,0000 & 13423,333 &, 772 &. &, 920 \\
\hline item14 & 1290,0000 & 14111,111 &, 762 &. &, 922 \\
\hline item15 & 1290,0000 & 13644,444 &, 755 &. &, 920 \\
\hline item16 & 1289,0000 & 13654,444 &, 859 &. &, 923 \\
\hline item17 & 1289,0000 & 13410,000 &, 921 &. &, 922 \\
\hline item18 & 1287,0000 & 14090,000 &, 842 &. &, 923 \\
\hline item19 & 1294,0000 & 13760,000 &, 727 &. &, 919 \\
\hline item20 & 1290,0000 & 14000,000 &, 855 &. &, 920 \\
\hline item21 & 1291,0000 & 13321,111 &, 842 &, 924 \\
\hline item22 & 1294,0000 & 13493,333 &, 814 &, 926 \\
\hline item23 & 1294,0000 & 13404,444 &, 948 &. &, 920 \\
\hline item24 & 1299,0000 & 13765,556 &, 826 &. &. \\
\hline item25 & 1289,0000 & 13410,000 &, 721 &. &. \\
\hline
\end{tabular}




\begin{tabular}{llllll}
\hline item26 & 1291,0000 & 13832,222 &, 721 &. &, 924 \\
\hline item27 & 1292,0000 & 12906,667 &, 837 &. &, 917 \\
\hline item28 & 1290,0000 & 13644,444 &, 755 &. &, 920 \\
\hline item29 & 1292,0000 & 13417,778 &, 789 &. &, 920 \\
\hline item30 & 1292,0000 & 14017,778 &, 740 &. &, 923 \\
\hline
\end{tabular}

Tabel 6.1 menunjukkan bahwa nilai setiap butir instrumen pada kolom correlated item total correlation lebih besar dari nilai $\mathrm{r}_{\text {tabel }}$ dengan taraf signifikansi 5\% atau 0,707, artinya, keseluruhan butir soal pada instrumen koesioner variabel kompetensi pedagogik guru (X1) adalah valid. Selanjutnya, nilai setiap butir instrumen pada kolom Cronbach's Alpha if Item Deleted lebih besar dari nilai $\mathrm{r}_{\text {tabel }}$ dengan taraf signifikansi 5\% $(0,7)$ maka keseluruhan butir instrumen dinyatakan reliabel.

\section{Deskripsi Kompetensi Profesional Guru di SMK Negeri 4 Kota Makassar}

Tabel 4.9 Tabulasi Hasil Analisis Deskriptif Data Variabel X2

\begin{tabular}{|c|c|c|c|c|}
\hline No. & Sampel & $\mathrm{X} 2$ & Mean & Keterangan \\
\hline 1 & Guru 01 & 37 & 4,63 & Sangat Baik \\
\hline 2 & Guru 02 & 40 & 5,00 & Sangat Baik \\
\hline 3 & Guru 03 & 35 & 4,38 & Sangat Baik \\
\hline 4 & Guru 04 & 35 & 4,38 & Sangat Baik \\
\hline 5 & Guru 05 & 40 & 5,00 & Sangat Baik \\
\hline 6 & Guru 06 & 34 & 4,25 & Sangat Baik \\
\hline 7 & Guru 07 & 32 & 4,00 & Baik \\
\hline 8 & Guru 08 & 30 & 3,75 & Baik \\
\hline 9 & Guru 09 & 30 & 3,75 & Baik \\
\hline 10 & Guru 10 & 35 & 4,38 & Sangat Baik \\
\hline 11 & Guru 11 & 32 & 4,00 & Baik \\
\hline 12 & Guru 12 & 31 & 3,88 & Baik \\
\hline 13 & Guru 13 & 33 & 4,13 & Baik \\
\hline 14 & Guru 14 & 35 & 4,38 & Sangat Baik \\
\hline 15 & Guru 15 & 40 & 5,00 & Sangat Baik \\
\hline 16 & Guru 16 & 35 & 4,38 & Sangat Baik \\
\hline 17 & Guru 17 & 40 & 5,00 & Sangat Baik \\
\hline 18 & Guru 18 & 38 & 4,75 & Sangat Baik \\
\hline 19 & Guru 19 & 40 & 5,00 & Sangat Baik \\
\hline 20 & Guru 20 & 40 & 5,00 & Sangat Baik \\
\hline 21 & Guru 21 & 34 & 4,25 & Sangat Baik \\
\hline 22 & Guru 22 & 37 & 4,63 & Sangat Baik \\
\hline 23 & Guru 23 & 35 & 4,38 & Sangat Baik \\
\hline 24 & Guru 24 & 35 & 4,38 & Sangat Baik \\
\hline 25 & Guru 25 & 30 & 3,75 & Baik \\
\hline 26 & Guru 26 & 40 & 5,00 & Sangat Baik \\
\hline 27 & Guru 27 & 35 & 4,38 & Sangat Baik \\
\hline 28 & Guru 28 & 37 & 4,63 & Sangat Baik \\
\hline 29 & Guru 29 & 38 & 4,75 & Sangat Baik \\
\hline 30 & Guru 30 & 38 & 4,75 & Sangat Baik \\
\hline 31 & Guru 31 & 40 & 5,00 & Sangat Baik \\
\hline 32 & Guru 32 & 33 & 4,13 & Baik \\
\hline 33 & Guru 33 & 32 & 4,00 & Baik \\
\hline 34 & Guru 34 & 30 & 3,75 & Baik \\
\hline 35 & Guru 35 & 35 & 4,38 & Sangat Baik \\
\hline 36 & Guru 36 & 35 & 4,38 & Sangat Baik \\
\hline
\end{tabular}

Ada empat kompetensi profesional guru yang menjadi indikator penilaian dalam penelitian ini yaitu (1) menguasai materi, struktur, konsep, dan pola pikir keilmuan, (2) menguasai standar kompetensi dan kompetensi dasar mata pelajaran pengembangan yang diampuh, (3) mengembangkan materi pembelajaran yang kreatif, (4) mengembangkan keprofesionalan secara berkelanjutan dengan melakukan tindakan reflektif. Deskripsi kompetensi profesional terkait empat indikator tersebut pada guru SMKN 4 Makassar tergambar dalam tabel berikut: 


\begin{tabular}{lllll}
\hline 37 & Guru 37 & 40 & 5,00 & Sangat Baik \\
\hline 38 & Guru 38 & 38 & 4,75 & Sangat Baik \\
\hline 39 & Guru 39 & 40 & 5,00 & Sangat Baik \\
\hline 40 & Guru 40 & 35 & 4,38 & Sangat Baik \\
\hline
\end{tabular}

Dari tabel tersebut, dapat dibuat distribusi frekuensi kompetensi profesional guru di SMKN 4 Makassar seperti pada tabel berikut:

Tabel 4.10 Distribusi Frekuensi Variabel Kompetensi Profesional Guru

\begin{tabular}{cccc}
\hline Rata-Rata Skor & Frekuensi & Persentase & Penafsiran \\
\hline $4,2-5,0$ & 30 & 75 & Sangat baik \\
\hline $3,4-4,1$ & 10 & 25 & Baik \\
\hline $2,6-3,3$ & 0 & 0 & Cukup Baik \\
\hline $1,8-2,5$ & 0 & 0 & Kurang baik \\
\hline $1,0-1,7$ & 0 & 0 & Sangat kurang baik \\
\hline Jumlah & 40 & 100 & \\
\hline
\end{tabular}

Berdasarkan tabel di atas, diketahui 30 guru di SMKN 4 Makassar dengan persentase 75\% memiliki kompetensi profesional dengan kategori sangat baik dan sepuluh orang guru lainnya atau $25 \%$ memiliki kompetensi dengan kategori baik. Tidak ada guru yang memiliki kompetensi profesional dengan kategori cukup baik, kurang baik, ataupun sangat tidak baik atau buruk.

\section{A. Pembahasan}

Secara deskriptif, kompetensi pedagogik guru di SMKN 4 Makassar dapat dinyatakan memuaskan karena secara klasikal, $80 \%$ guru memiliki kompetensi pedagogik dengan kategori sangat baik. Selanjutnya, kompetensi profesional guru, kepuasan kerja, dan kinerja guru di SMKN 4 Makassar juga dapat dinyatakan memuaskan karena secara kalsikal, 75\% guru memiliki kompetensi profesional dengan kategori sangat baik, 100\% memiliki tingkat kepuasan kerja dengan kategori sangat baik, dan 97,50\% guru memiliki kinerja dengan kategori sangat baik.

Hasil kompetensi pedagogik guru sesuai dengan hasil observasi, wawancara, serta kajian dokument yang dilakukan oleh peneliti. Guru-guru memiliki kompetensi dalam mengajar yang sangat baik, karena menguasai bahan ajar, merancangan rencana pembelajaran dengan baik, serta mampu mengelolah kelas dengan sangat baik. Selanjutnya, guru memiliki kompetensi profesional yang sangat baik dibuktikan dengan penguasan dan penghayatan atas tugas profesional yang harus dilakukan.

Terkait dengan pengaruh antara beberapa variabel bebas terhadap variabel terikat dalam penelitian ini, Rivai (2004) menegaskan bahwa lembaga (dalam hal ini SMKN 4 Makassar) memiliki fungsi strategis untuk mengembangkan SDMnya yaitu para guru. Rivai menambahkan bahwa berbagai cara dapat ditempuh untuk meningkatkan kompetensi SDM pada suatu lembaga seperti pelatihan dan pendidikan. Sejalan dengan hal tersebut, SMKN 4 Makassar memberikan dukungan penuh untuk meningkatkan kompetensi guru baik itu dalam bentuk pelatihan maupun pendidikan. Sejalan dengan pandangan Rivai, Sondang P. (2001) menegaskan bahwa semakin baik manajemen SDM suatu organisasi maka semakin baik pula outputnya terhadap perkembangan organiasi. Manajemen SDM yang baik akan melahirkan manuasi yang berkeompeten, terampil, dan loyal terhadap kinerja profesinya.

Kemajuan sebuah organisasi (dalam hal ini SMKN 4 Makassar) sangat ditentukan oleh kualitas guru yang ada di dalamnya. Robbins (2001) berpendapat bahwa perilaku organisasi terkait perkembangan maupun kemajuan di dalamnya sangat bergantung pada kinerja profesional tenaga pekerja yang ada di dalamnya. oleh karena itu, pendapat Robbins tersebut sangat relevan dengan hasil penelitian ini bahwa kemajuan atau perkembangan yang dialami oleh SMKN 4 Makassar sangat di dukung oleh kinerja guru itu sendiri. Kinerja guru tersebut tentulah tidak telepas dari pengerauh beberapa faktor seperti kompetensi guru (dalam hal ini pedagogik dan kompetensi progesional, dan kepuasan kerja.

Terkait dengan hasil penelitian ini, Mulyasa (2007) mengemukakan bahwa semakin berkompeten seseorang atau semakin tinggi keterampilan dan kompetensi seseorang maka akan semakin baik pula kinerja yang 
ditampilkan. Penelitian ini membuktikan bahwa $80 \%$ guru di SMKN 4 Makassar memiliki kompetensi pedagogik dengan kategori sangat baik dan $75 \%$ memiliki kompetensi profesional dengan kategori sangat baik. Hal ini sejalan dengan hasil kinerja guru sebesar $97,50 \%$ guru memiliki kinerja sangat baik.

\section{KESIMPULAN}

Berdasarkan perolehan data dan hasil analisisnya disimpulkan hasil penelitian ini adalah:

Ada pengaruh yang signifikan kompetensi pedagogik terhadap kinerja guru di SMK Negeri 4 Makassar yang ditunjukkan dengan hasil uji $\mathrm{T}$ parsial bahwa nilai Thitung variabel kompetensi pedagogik guru di SMKN 4 Makassar sebesar 2,982 lebih besar dari nilai Ttabel pada $\mathrm{Dk}=\mathrm{N}-2=38$ dengan taraf signifikansi $5 \%$ yaitu $1,684 \quad(2,982>1,684)$. Selanjutnya, nilai signifikansi hitung variabel kompetensi pedagogik guru di SMKN 4 Makassar 0,026 lebih kecil dari nilai signifkansi yang ditetapkan yaitu 0,05

Ada pengaruh yang signifikan kompetensi profesional terhadap kinerja guru di SMK Negeri 4 Makassar yang ditunjukkan dengan nilai Thitung sebesar 2,658 lebih besar dari nilai Ttabel pada $\mathrm{Dk}=\mathrm{N}-2=38$ dengan taraf signifikansi $5 \%$ yaitu $1,684 \quad(2,658>1,684)$. Selanjutnya, nilai signifikansi hitung variabel kompetensi profesional guru di SMKN 4 Makassar 0,038 lebih kecil dari nilai signifkansi yang ditetapkan yaitu 0,05

Ada pengaruh yang signifikan kepuasan kerja terhadap kinerja guru di SMK Negeri 4 Makassar yang ditunjukkan dengan nilai Thitung sebesar 3,885 lebih besar dari nilai Ttabel pada $\mathrm{Dk}=\mathrm{N}-2=38$ dengan taraf signifikansi $5 \%$ yaitu $1,684 \quad(3,885>1,684)$. Selanjutnya, nilai signifikansi hitung variabel kepuasan kerja guru di SMKN 4 Makassar 0,013 lebih kecil dari nilai signifkansi yang ditetapkan yaitu 0,05 .

Ada pengaruh yang signifikan antara kompetensi pedagogik, kompetensi profesional, dan kepuasan kerja terhadap kinerja guru di SMK Negeri 4 Makassar. Hal ini dibuktikan dengan nilai $F_{\text {hitung }}$ sebesar 3,741 lebih besar dari nilai $\mathrm{F}_{\text {tabel }}$ pada $\mathrm{Dk}=\mathrm{N}$ $3=37$ dengan taraf signifikansi 5\% yaitu $2,950 \quad(3,741>2,950)$. Selanjutnya, nilai signifikansi hitung sebesar 0,039 lebih kecil dari nilai signifikansi yang ditetapkan yaitu 0,05 atau $5 \%$.

\section{DAFTAR PUSTAKA}

Agung, Lilik. 2007. Human Capital Competencies. Jakarta: Elex Media Komputindo

Anonim No.14 Tahun 2005. Tentang Guru dan Dosen. Departemen Pendidikan Nasional Republik Indonesia: Jakarta.

Anonim Nomor 19 / 2005. Tentang Standar Nasional Pendidikan.

Arifin. 2011. Kompetensi Guru dan Strategi Pengembangannya. Jakarta: Lilin Persada Press

Darsono. 2011. Manajemen Sumber Daya Manusia Abad Ke 21. Jakarta: Nusantara Consulting

Davis K, Newstrom JW, 2001. Perilaku dalam Organisasi. Jilid 1, Terjemahan. Jakarta: Penerbit Erlangga.

Eko Pujiastuti, Tri Joko Raharjo, A. Tri Widodo. 2012. "Kompetensi Profesional, Pedagogik Guru IPA, Persepsi Peserta didik Tentang Proses Pembelajaran, dan Konstribusinya Terhadap Hasil Balajar IPA Di SMP/MTs Kota Banjarbaru”. Jurnal Innovative Journal of Curriculum and Educational Technology Vol. 1 No. 1

Ghozali, Imam. 2006. Aplikasi Analisis Multivariate Dengan Program SPSS. Semarang: Badan Penerbit Universitas Diponegoro.

Hamzah B. Uno. (2011). Teori Motivasi dan Pengukurannya: Analisis di Bidang Pendidikan. Jakarta: Bumi aksara

Hasibuan, Malayu S. P. 2008. Manajemen Sumber Daya Manusia. Jakarta: PT. Bumi Aksara.

Husaini Usman. 2006. Manajemen. Jakarta: Bumi Aksara

Hutapean, Parulian. 2008. Kompetensi Plus: Teori, Desain, Kasus, dan Penerapan Untuk HR dan Organisasi yang Dinamis. Jakarta: Gramedia Pustaka.

Jones, Gareth R. \& George, Jennifer M. (2008). Contemporary management (fifth edition). USA: McGRAWhillInternational

Majid, A. 2005. Perencanaan Pembelajaran. Bandung: Remaja Rosdakarya.

Nurrohmadi, Latif. 2011. Pengaruh Motivasi dan Kepuasan Kerja Terhadap Kinerja 
Guru. Skripsi. Fakultas Ekonmi dan Bisnis. Universitas Islam Negeri Syarif Hidayatullah: Jakarta

Peraturan Menteri Pendidikan Nasional No. 16 Tahun 2007 Tentang Standar Kualifikasi Akademik dan Kompetensi Guru.

Sanjaya,Wina. 2007. Strategi Pembelajaran berorientasi Standar Proses Pendidikan. Jakarta: Fajar interpratama Offset

Sukardi. 2005. Metodologi Penelitian Pendidikan Kompetensi dan Praktiknya. Jakarta: Bumi Aksara.

Suliyanto. 2011. Ekonometrika Terapan: Teori dan Aplikasi dengan SPSS. Yogyakarta: Andi.
Suprayitno Riyanto dan Sapar. 2011. Pengantar Metode Penelitian. Bogor: Makaira Printing Plus.

Sutrisno, Edy. 2009. Manajemen Sumber Daya Manusia. Edisi Pertama, Cetakan Pertama, Penerbit Kencana, Jakarta

Wibowo. 2010. Manajemen Kinerja. Jakarta: Raja Grafindo Persada

Wirawan. 2009. Evaluasi Kinerja Sumber Daya Manusia : Teori Aplikasi dan Penelitian. Jakarta: Salemba Empat.

Wonseka, Marten. 2011. Pengaruh Kompetensi Pedagogik dan Motivasi Kerja Terhadap Kinerja Guru SMA Negeri di Kabupaten Minahasa Manado: UNIMA. 